\title{
Teachers Technological Capability as Digital Immigrants in Learning from Home Activities
}

\author{
https://doi.org/10.3991/ijet.v16i07.21229 \\ Prawinda Putri Anzari, Imamul Huda Al Shiddiq, \\ Seli Septiana Pratiwi, Megasari Noer Fatanti \\ Universitas Negeri Malang, Malang, Indonesia \\ Daniel Fritz V. Silvallana $(\bowtie)$ \\ Davao del Norte State College, Panabo, Phillipines \\ danielfritz.silvallanaddnsc.edu.ph
}

\begin{abstract}
This article aims at the ability of teachers who are digital immigrants to use digital technology during their learning at home during the Covid19 pandemic. This research was quantitative research in the form of descriptive statistics using survey methods in data collection. The survey was given to 139 high school teachers who live in Java. The validity of the research instrument was tested by using the product-moment correlation test. While the reliability of the research instrument was tested utilizing the Cronbach Alpha reliability test, the result of this study is that high school teachers have a high level of use of digital technology. Besides, it was also found that age affects the ability to use technology. The higher the teacher's age, the lower their ability to use digital technology. Meanwhile, the lower the age, the higher the individual can use digital technology. When teachers have a high level of use of digital technology, it is hoped that learning activities at home can run optimally. Apart from the level of the teacher's technology skills, of course, other aspects make learning activities at home optimal. These other aspects also need to be develop.
\end{abstract}

Keywords - Online learning, digital immigrants, technology capability, digital technology

\section{$1 \quad$ Introduction}

In May 2020, the Indonesian Minister of Education and Culture issued a Circular on Guidelines for Organizing Learning from Home in an Emergency for the Spread of Covid-19. The circular was issued to continue to fulfilltion services while preventing the spread and transmission of Covid-19 in academic units. Home learning means that both teachers and students must be able to transform from conventional learning conditions to online learning, and this cannot be done easily in one night. Changes in conditions during a pandemic like this will certainly encounter many obstacles and chal- 
lenges. [1]. Because no one knows when the Covid-19 pandemic will end, every academic instituions around the world decided to implement online learning by using information and communication technology. [2].

Changes in learning and teaching will indeed never be separated from the role of teachers [3], especially changes to online learning patterns. Teachers must be prepared for various learning conditions, student conditions, and the ability of teachers to utilize technology in the process of teaching. Therefore, the object that will be highlighted in this paper regarding home learning policies during a pandemic is school teachers. With the existence of online home-study policy, of course, teachers are required to have expertise in the field of digital technology. Online learning is not new. Since 2016 the Government has encouraged academic teachers from elementary school to university level to take advantage of information and communication technology in the learning process. The development of information and communication technology has had a significant influence on the world of education, especially in planning, processing and evaluation activities. Teachers can provide services without having to deal directly with students. Likewise, students can get a wide range of information from various sources through cyberspace using computers or the internet [4].

Research [5] stated that with online learning activities during a pandemic, there will be many conveniences such as accessibility and flexibility. It is said that online learning is easy to reach and can even reach remote rural areas. However, the fact is that such convenience does not apply in Indonesia because there are still many areas in Indonesia, especially rural areas that have not strong enough signal power. Research [6] stated, only about $11 \%$ of teachers in Indonesia have mastered communication and information technology devices to carry out online learning. Apart from their limited technological capabilities, teachers also have other obstacles, such as inadequate technological devices and unstable internet networks. Since last May, there has been a lot of news in the timeline reporting problems of online learning, such as low teacher control, lack of infrastructure, difficult signal access in some areas, to a lack of digital technology literacy that hinders learning. According to [7] reports from regions in Indonesia show that the application of online education has not been optimal, especially in remote areas with limited internet technology and networks.

Research [8] stated that during the Covid-19 pandemic, academic institutions only focused on transferring educational content to digital, not on teaching methods and online delivery. This drastic change is not matched by the technological abilities of the teachers themselves. In fact, teachers have a very large function as facilitators of online learning, not only being sources and providers of knowledge.[9]. If the teacher has high technological skills, it is hoped that online learning can be carried out effectively. Also, if both teachers and students can utilize computer and technology in academic activity then they will have high level of confidence and positive mentality.[10].

Research [11] stated that based on his study, there are eight ways in which technology can improve the quality of education, namely: 1) better models and simulations; 2 ) global learning; 3) virtual manipulation; 4) investigation and censorship; 5) more efficient assessment; 6) multimedia and storytelling; 7) electronic books, and 8) planning games. All of which indicates that the content and technological processes must be based on interactivity and proximity to the environment and student knowledge. 
Based on the 2018 Internet Service Providers Association (APJII) survey, most internet users in Indonesia are teenagers aged 15-19 years. When included in the student category, high school students are students entering the age phase who have the highest ability to use the internet in Indonesia. This generation is also called digital native, which is a generation that is familiar with technology from an early age and has no difficulty adapting to developments in information technology. Meanwhile, the older a person is, the lower the level of their internet use is. In the age group of teachers or adults, this generation is called digital immigrants, namely individuals who use technology in adulthood so they still often have to adapt to existing technological advances. If it is related to the conditions of learning at home, teenagers or high school students are the cluster of students who use the internet the most, so high school students as digital natives should adapt more quickly to the concept of online learning. However, the ease of adapting to using digital technology is not necessarily shared by all high school teachers.

Research [12] stated that the generation born after 1980 is categorized as digital native because they grew up with digital media and spent a lot of time interacting with new digital devices and browsing online. With the concept of digital native and digital immigrant in the world of technology, it shows that there is a gap between students, young teachers, and senior teachers in competence in mastering technology. Due to this perceived gap, there is a concern that teachers will not be adequately prepared to facilitate students using the latest information and communication technology tools. If digital skills only stick with students, then what about teachers? What skills do teachers need to become facilitators of online learning for digital natives? [13].

Age differences between high school students and teachers, as well as differences in behavior in using technology, can create barriers in the learning process. So in this article, the authors want to see how the technology skills of teachers during online learning in a pandemic era, and see if there is a relationship between teacher age and their technological capabilities.

\section{Literature Review}

\subsection{Teacher as a digital immigrant}

One of the essential components in education is the teaching staff. Educators must be able to respond to the needs of students and their environment who are struggling with virtual world activities. Even students today are children who are referred to as digital natives [14]. Digital native is a term for people born in the digital era, Generation $\mathrm{X}$ and younger. This group is also referred to as the: iGeneration" or is described as having been born with digital DNA. In contrast, the term digital immigrant refers to those born before about 1964 and who grew up in a pre-computer world. The terms digital immigrant and digital immigrants will never deal with technology as naturally as those who grew up with it [15]. 
Digital natives are characterized as digitally fluent with a variety of technologies because of their immersion in digital technology during their childhood and adolescence when neural plasticity is high. This phenomenon habituates the young generation to specific behaviors that affect how these generations think and learn [16]. Meanwhile, Digital Immigrants refers to individuals who were born before the existence of digital technology [12]. Although Digital Immigrants are also users of information and communication technology, they begin to use these digital devices and technology during their adulthood.

Based on the 2018 APJII survey, the level of internet users has decreased with increasing age. This condition causes the emergence of a technology gap between generations. This intergenerational gap arises due to a lack of expertise to access various kinds of information through digital technology. Therefore, digital immigrants tend to experience greater technological stuttering than the teenage generation when dealing with the swift flow of communication technology developments. [17].

Although many Digital Immigrants have developed their digital literacy and adapted to the use of technology, their behavior in using technology is still very different from that of digital natives [18]. This difference in behavior occurs because of differences in age and generation levels. Several previous studies have shown that younger users born after the 1980s are digital natives, while adults born before the 1980s are digital immigrants. However, this classification is problematic because most of the previous studies only focused on the behavior of digital natives [19].

Students who carry out online learning can be classified as Digital Natives because they were born in the era of technology and have been accustomed to using digital technology from an early age. Meanwhile, the teachers who teach are not necessarily all Digital Natives. The gap between behavior using digital technology is what is interesting to discuss, especially with the policy of learning from home during the COVID19 pandemic.

\subsection{Online learning in pandemic times}

The use of multimedia computers and the internet in education is indisputable [9]. One of the solutions offered so that learning activities can continue during a pandemic is to use technology to increase the likelihood that students can continue their learning activities. Based on the coverage of the Kompas Team, schools in Indonesia have tried to carry out online learning or distance learning, one of which is in the province of Banten, which holds online teaching and learning activities. Teachers and students are increasingly familiar with the technology used for online learning. The applications used are WhatsApp Group, Zoom Cloud Meeting, Google Classroom, Google Form, and e-mail. Teachers and students use these various applications according to their respective conditions and abilities.

According to Tearle [20], the success of the integration of educational technology in teaching and learning activities is complex and influenced by various factors. For example, in high schools in England, three prominent themes were identified, namely the individual aspect, the implementation process and the school organization . Individual themes are divided into four factors, namely openness to technology, teacher attitudes, 
knowledge and skills, and teacher work and time load. These various factors indicate that if there is one or more that do not support it will cause the effectiveness of integrated learning to be disrupted, even to the point of failure [21].

But in practice, online learning is not without problems. In some countries, it was reported that among those who adopted online learning, the actual benefits were much less than expected [22]. Network problems, lack of training, and lack of awareness were stated as the main challenges faced by educators. Lack of awareness was stated as the most crucial reason by those who did not adopt online learning, followed by a lack of interest and doubts about the usefulness of online learning. Lack of attendance, lack of personal touch, lack of interaction due to connectivity issues were found to be significant drawbacks of online learning. [23].

\section{Method}

The main objective of this study is to determine in general the level of technology use by teachers during online learning in the midst of the Covid-19 pandemic. The research sample was 139 teachers from various disciplines (such as sociology, Indonesian language, geography, mathematic, etc.) who tutored students at the high school level. The research was conducted in 6 provinces in Java Island. Java Island was chosen because as many as $50 \%$ more internet users live in Java Island. The data collected in this study are to present the ability of teachers to use technology in the online sharing process. An online survey technique was used to gather data about the level of teacher technology mastery in Java. 11 items questionnaire was used to assess the ability to use technology in online learning.

This research was a quantitative descriptive study that explains the research data obtained in a specific manner without correlating one variable with other variables [24]. Descriptive statistics are only limited to describing or describing data so that it is easy to understand [25]. The primary data collection method was carried out by surveying through a questionnaire consisting of 36 questions in total. In comparison, the indicator variable for the level of technology use contained 11 questions, so that the type of research data is nominal data. Descriptive data analysis can be carried out in various ways, such as data size, the level of data variability (standard deviation, variance), to the shape of the data size That is, Data analysis does not include looking for relationships or influences between one variable and another. In descriptive statistics, data homogeneity is very important.

The questionnaire that had been compiled was then tested, involving 139 respondents. Respondents were high school teachers on Java Island who did online learning during the learning period from home. Domicile in Java Island was chosen because more than $50 \%$ of internet users in Indonesia are on the island of Java.. Questions in the form of self-assessment with four levels of scale, namely; 1) Disagree; 2) tend to disagree; 3) Tend to Agree; 4) and Agree. The questionnaire was then distributed through online media, namely by using the google form survey platform. The duration of filling out the questionnaire via google form was carried out during the period of time from 26 June 2020 to 8 July 2020 . Online data collection can be done with several 
considerations including 1) wide geographic range of respondents: 2) limited time for data collection: 3) target respondents who are Internet user; and 4) the level of sensitivity of the information required so that it requires a certain degree of anonymity [26]. The findings of this study are not representative of the entire population.

The validity of the research instrument was tested by using the product-moment correlation test. In contrast, the reliability of the research instrument was tested by using Alpha Cronbach reliability test. The results of both can be seen in the table below:

Table 1. Instrument Validity and Reability

\begin{tabular}{|l|c|c|c|c|}
\hline \multicolumn{1}{|c|}{ Statements } & Val. & Rel. & r table & Decision \\
\hline I can use communication tools & 0,815 & 0,924 & 0,218 & Val \& Rel \\
\hline I can use online learning application & 0,822 & 0,923 & 0,218 & Val \& Rel \\
\hline I am capable of using smartphone & 0,754 & 0,927 & 0,218 & Val \& Rel \\
\hline I am capable of using the laptop & 0,872 & 0,92 & 0,218 & Val \& Rel \\
\hline I am capable of using the computer & 0,847 & 0,921 & 0,218 & Val \& Rel \\
\hline I am capable of using tablet or iPad & 0,779 & 0,926 & 0,218 & Val \& Rel \\
\hline I am capable to search for information via google & 0,69 & 0,929 & 0,218 & Val \& Rel \\
\hline I am able to send email & 0,695 & 0,929 & 0,218 & Val \& Rel \\
\hline I am able to create online classroom & 0,787 & 0,925 & 0,218 & Val \& Rel \\
\hline I am able to upload material on an online learning application & 0,733 & 0,927 & 0,218 & Val \& Rel \\
\hline I am able to assess student assignments on the online application & 0,729 & 0,927 & 0,218 & Val \& Rel \\
\hline
\end{tabular}

Of all the statements tested in this study, it was found that all of them were valid and reliable with $r$ table of 0.218 and an error level of 0.01 , which means that all indicators that have been formulated can measure the variable level of mastery of information technology at the level of empirical reality.

\section{$4 \quad$ Result and Discussion}

Table 2. Mean Value of Mastery of Technology Level

\begin{tabular}{|l|l|c|c|c|c|c|c|}
\hline Code & \multicolumn{1}{|c|}{ Statements } & $\mathbf{1}$ & $\mathbf{2}$ & $\mathbf{3}$ & $\mathbf{4}$ & $\mathbf{n}$ & mean \\
\hline $\mathrm{X} 1$ & I can use communication tools & 15 & 9 & 25 & 90 & 139 & 3,37 \\
\hline $\mathrm{X} 2$ & I can use online learning application & 15 & 20 & 38 & 66 & 139 & 3,12 \\
\hline $\mathrm{X} 3$ & I am capable of using smartphone & 3 & 5 & 16 & 115 & 139 & 3,75 \\
\hline $\mathrm{X} 4$ & I am capable of using the laptop & 7 & 12 & 24 & 96 & 139 & 3,50 \\
\hline $\mathrm{X} 5$ & I am capable of using the computer & 9 & 13 & 27 & 90 & 139 & 3,42 \\
\hline X6 & I am capable of using tablet or iPad & 11 & 20 & 31 & 77 & 139 & 3,25 \\
\hline X7 & I am capable to search for information via google & 4 & 7 & 18 & 110 & 139 & 3,68 \\
\hline X8 & I am able to send email & 4 & 4 & 11 & 120 & 139 & 3,78 \\
\hline X9 & I am able to create online classroom & 12 & 19 & 34 & 74 & 139 & 3,22 \\
\hline X10 & $\begin{array}{l}\text { I am able to upload material on an online learning applica- } \\
\text { tion }\end{array}$ & 5 & 13 & 37 & 84 & 139 & 3,44 \\
\hline X11 & $\begin{array}{l}\text { I am able to assess student assignments on the online appli- } \\
\text { cation }\end{array}$ & 7 & 12 & 29 & 91 & 139 & 3,47 \\
\hline & \multicolumn{1}{|l|}{ Total Mean } & & & 3,45 \\
\hline
\end{tabular}


The table above shows the mean level of mastery of technology based on each statement item compiled in the research instrument. The index or score for each item is on a scale of 4 (four), namely 1 the lowest and 4 the highest. The more the score approaches 4 , then the majority of respondents agree with the statements conveyed in each item. This index means that the respondent states that what is conveyed in the research instrument is following what happened to the respondent. Item statement X1 which states about the ability of respondents to use communication tools has a mean of 3.37; Item statement X2 which states about the ability of respondents to use online learning applications has a mean of 3.12; Item statement X3 which states the ability of respondents to use devices has a mean of 3.75; Item X4 statement which states the ability of the respondent to operate a laptop has a mean of 3.50; Item X5 which states the ability to use a computer has a mean of 3.42; Item X6 which states the ability of respondents to use a tablet / iPad has a mean of 3.25; Item X7 which behaves ability respondents searched for information through google with a mean of 3.68; Item X8 which is called the capability of the respondent to send an email with a mean of 3.78; Item X9 which is called the ability to create online classrooms with a mean of 3.22; Item X10 which reveals the ability to upload material in learning applications online has a mean of 3.44; and item X11 which shows the ability to assess student assignments in online applications has a mean of 3.47 .

All statement items in the questionnaire have a mean of more than 3.00 on a scale of 4, which means that the respondent's ability to operate information technology tends to be high. It can also be seen from the total mean of all statement items which shows the number 3.45. The data obtained shows that the level of technology use of high school teachers in Java in online learning during the pandemic can be said to be high.

Table 3. Correlations

\begin{tabular}{|l|l|c|c|}
\hline & & Umur & TPT \\
\hline \multirow{3}{*}{ Umur } & Pearson Correlation & 1 & $-.352^{* *}$ \\
\cline { 2 - 4 } & Sig. (2-tailed) & & .000 \\
\cline { 2 - 4 } & $\mathrm{N}$ & 139 & 139 \\
\hline \multirow{3}{*}{ TPT } & Pearson Correlation & $-.352^{* *}$ & 1 \\
\cline { 2 - 4 } & Sig. (2-tailed) & .000 & 139 \\
\cline { 2 - 4 } & $\mathrm{N}$ & 139 & \\
\hline
\end{tabular}

**. Correlation is significant at the 0.01 level (2-tailed).

From the correlation table above, it is found that the age of the respondent influences the level of mastery of technology with a Pearson correlation $r$ score of -0.352 . The $r$ score shows a correlation between the age variable and the Technology Mastery Level variable. It can be concluded after comparing the $r$ score with the $r$ table of 0.218 , where the $r$ score is greater than the $r$ table. From the $r$ score, it can also be concluded that the direction of the relationship between the Age variable and the Technology Mastery Level variable is negative, namely -0.352 . It means that the higher or older the respondent's age, the lower the level of mastery of information technology. Meanwhile, the lower the age, the higher the level of mastery of information technology. 


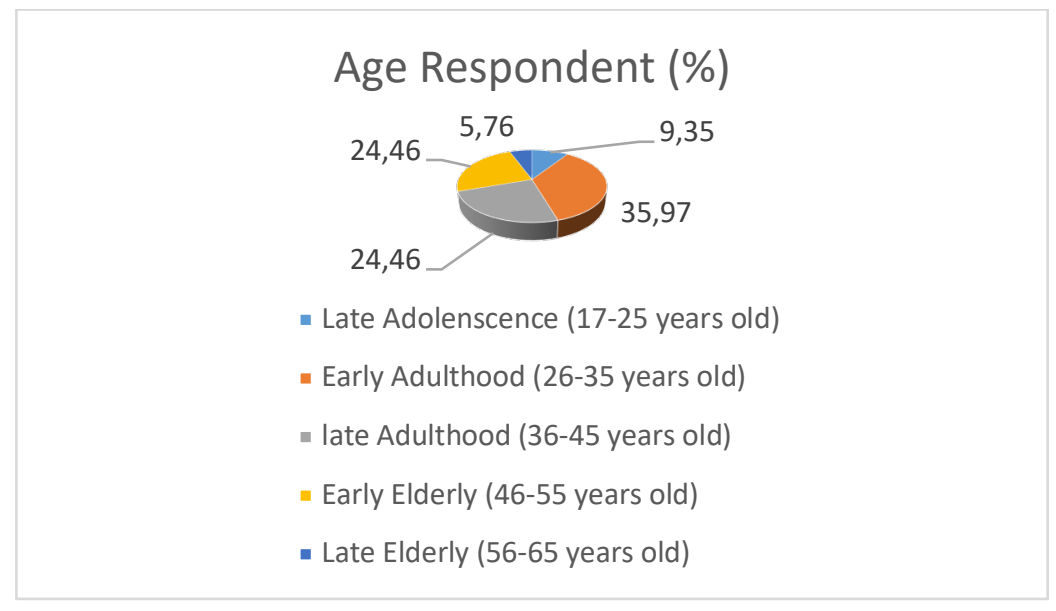

Fig. 1. Age Respondent

Figure 1 shows the respondent's age from all 139 respondents, from late adolescence to early elderly. Most respondent from 26-35 years old. Based on that figure we can see that this research include the digital natives and digital immigrants as the respondents.

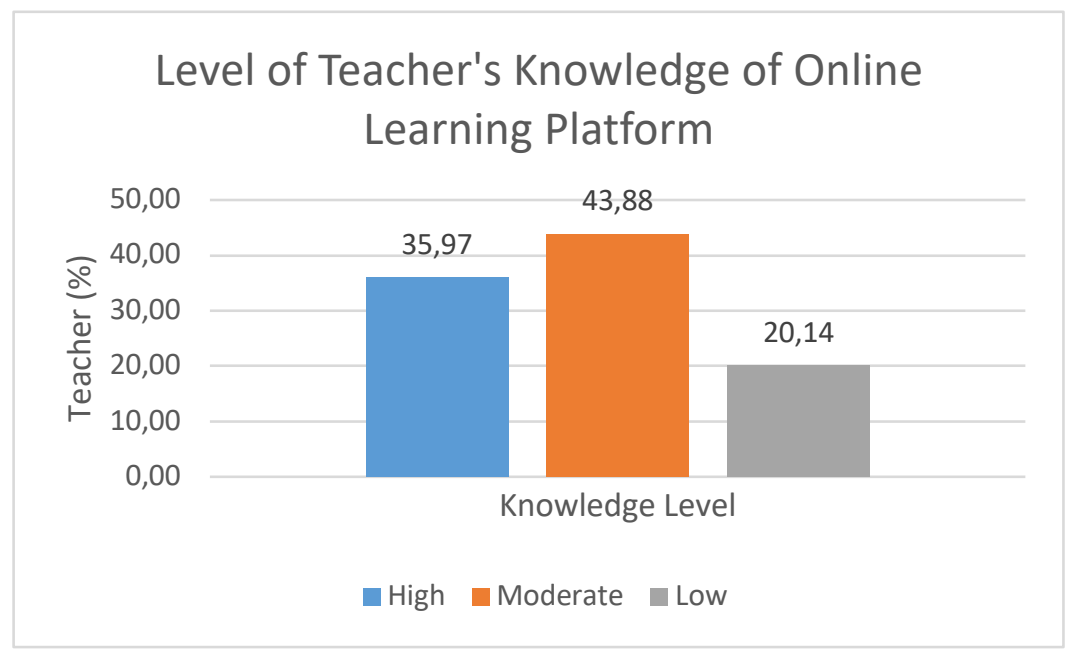

Fig. 2. Level of Teacher's Knowledge of Online Learning Platform

Figure 2 shows the level of teacher's knowledge of online learning platform. From 139 respondents, $35.7 \%$ respondents have high level knowledge of online learning platform, $43.88 \%$ respondents have moderate level knowledge and $20.14 \%$ respondents have low level knowledge. Online learning platform referred to Google Classroom, Edmondo, Zoom, Google Meet, Quipper and omline learning application provided by school or government. 
Table 4. Devices used by Respondent

\begin{tabular}{|l|c|}
\hline \multicolumn{1}{|c|}{ Devices } & Respondent \\
\hline Smartphone & 133 \\
\hline Laptop & 122 \\
\hline Computer & 28 \\
\hline Tablet/iPad & 11 \\
\hline
\end{tabular}

The devices used during online learning were varied. From Table 5 we can see that most of the teachers were using smartphone or laptop. Only few teachers were using computer and tablet/iPad. Almost all teachers who have smartphone also have laptop. During this pandemic era, teachers are required to use more than one device to do online learning, and since those devices are affordable and easy to carry, it became the most appropriate choice for most teachers.

\subsection{Adaptation of digital immigrant teachers with technology}

The generation who become teachers today varies, from the baby boomers generation, the $\mathrm{X}$ generation, to the $\mathrm{Y}$ generation or millennials generation. It can be seen from the respondents's profile who have diverse ages from late adolescence to elderly. It means there are three generations. Of course, these three generations have different characteristics in the use of technology. The baby boomers generation is materialistic and time-oriented [27]. This generation recognizes technology at an adult age so that almost the entire baby boomers generation is categorized as digital immigrants. Generation $\mathrm{Y}$ is a generation that was born in the early years of the development of technology and information such as the use of PCs, video games, cable tv and the internet [28]. Generation Y, or the millennial generation, is a generation that uses instant communication technologies such as email a lot. SMS, instant messaging and social media. In other words, the millennial generation is a generation that grew up in the era of the internet boom [29]. Although born in the era of information and communication technology development, not all millennial generations are digital natives. Some of them are also digital immigrants who do not optimize the use of communication and information technology.

Although based on the correlation table, it is found that the respondents who are high school teachers in Java Island, the higher the age, the lower the level of mastery of information and communication technology, the respondents' level of use of information technology is relatively high. So it can be concluded that all respondents can use information technology for online learning. It proves that high school teachers, who are categorized as digital immigrants, can adapt to using technology well and convey people's learning to high school students who are digital natives. A study [30] shows that age is not a determining factor in people's technology skills. The familiarity and experiences in using technology were more relevant to determine the notion of digital natives.

Most high school teachers currently are baby boomers or generation X, where they live in an environment that is not too dependent on the use of technology in everyday life. Their learning environment is traditional classroom learning, relying on instructors 
from the teacher and taking notes on books and on the blackboard to transfer information. This generation grew up being taught by instructors deploying a linear learning strategy in their instructional approach and collaborating on course material with their peers in conversation in one geographical location, either at school or by telephone where it was limited to the caller and receiver [31].

Teacher's age did not correlate with any technology usage inside or outside the classroom. The findings indicate that although young teachers have high technological abilities, they do not use "language" as used by students as digital natives [32]. Outside of learning, young teachers use technology to maintain social connections or pursuing personal interest [33], but teachers age and or outside-school technology experiences were not identified as crucial factors affecting teachers' technology integration. It echoes the finding from [30]. Therefore, we cannot take for granted that the gap in technology integration will be narrowed simply because more and more digital natives will be joining the teaching profession into the future.

\subsection{Teacher's technological capability for optimizing home learning}

In the world of education, the benefits of information and communication technology can be categorized into four. Namely first as a storehouse of knowledge, which can be used as a reference for the latest science, knowledge management, a network of experts in various fields of science, networks between educational institutions, centres for developing teaching materials, and curriculum development tools. Second, information and communication technology can also be used as a learning aid, namely (1) as a teaching aid which includes animation of events, student test tools, teaching reference sources, student performance evaluation, case simulations, virtual props, and communication media between teacher; (2) as a tool for interaction, which includes teacherstudent communication, study group collaboration, and integrated classroom management, and (3) as a student aid including interactive books, independent study, question exercises, illustration media, lesson simulations, student work tools, and communication media between students. Third, technology as a division facility, used as an electronic library, visual class, multimedia application, multimedia theatre class, private class, electronic board. Fourth, information and communication technology as infrastructure is technical support and applications for learning both on a medium and broadscale [34].

From the results of this study, it was found that high school teachers in Java had a high level of technology use in utilizing information and communication technology as learning tools. Teachers can operationalize technological devices such as cellphones, laptops, computers and tablets, and can create online classes, conduct online learning, and give an online score. The ability of high school teachers to use this technology is considered sufficient to provide provisions for studying at home during this pandemic. When teachers have a high level of technology use, it is hoped that online learning can be done optimally. Because after all, the competence of teachers is the primary determinant of the success of the learning process. The teacher will do everything possible so that the learning activities carried out are successful. To fulfil this, the teacher must 
play a role in directing and providing learning facilities to students so that the learning process runs adequately.

Meanwhile, from the survey regarding level of teacher's knowledge of online learning platform, most of the teachers understand how to use those online learning platform. It is proven by only $20.14 \%$ respondents have low level knowledge of online learning platform. This result is to be expected considering this teachers only had short time to change the learning concept into online learning. It can not be avoided that if teachers master the use of several online learning platform, then the online learning activity will be easier to be implemented. However, during this pandemic, it's not about what online learning method can bring the best quality, rather how the academic institutions adopt the online learning massively. [35]Institutions must focus on pedagogical issues and emphasize collaborative learning, case learning, and project-based learning through online instructions.[36].

Apart from the level of technical proficiency that teachers must have, several other aspects support the maximum running of online learning. Snelling and Fingal [37] explain that the International Society for Technology in Education (ISTE) in the United States has attempted to identify essential practices for successful online learning, such as; (1) Digital equity. Teachers and schools need to ensure that all participants involved have the tools; (2) Practice. Teachers must train themselves and their students in the applications and technologies they need to use when studying at home; (3) Give clear expectations to staff and parents. During online sharing activities, communication between administrators, staff, parents, and students is more critical than ever; (4) Take time to plan. Teachers must prepare one to two days in advance and adapt to the technology and platform that will be used for online learning; (5). Prepare personal needs, complete infrastructure. Teachers must ensure they have access to everything they need from home in case they are unable to return to school or bring home computers that are often used at school and move files to the cloud.

Although many teachers don't have equal technological skills compared to highschool students, they should have positive and open mind to accept the changes and have same purpose to improve student's achievements [38]. Integrating information technology in class can support learning activity effectively [39].

If the teacher already has an adequate level of technology use, it will be easy to develop and prepare other things to carry out online learning. Teachers can make the classroom simpler, communicate more intensely with parents using WhatsApp, Zoom, Google Meeting, and other applications, and monitor student activities during the learning period at home. Even though there are still many obstacles and obstacles in doing online learning, if the teacher already can use digital technology, it is hoped that the teacher can overcome other problems in online learning.

\section{Conclusion}

The learning from the home policy during the Covid-19 pandemic can work well if teachers as facilitators in learning can have competence in the use of communication and information technology. Although teachers are categorized as digital immigrants, 
in practice, when doing online learning, teachers have a relatively high level of technology use. The level of use of teacher technology is one factor in the success of online learning during a pandemic. However, of course, there are many other obstacles faced by teachers and students in online learning activities. The ability to use technology by teachers and students does not guarantee that teaching and learning activities can be fully optimal. Online learning also has constraints in terms of resources, facilities and infrastructure.

As a recommendation for the future, in addition to proficiency in using information and communication technology, teachers also need to have the ability to formulate effective curriculum and learning strategies through various online platforms. Teacher competence is the primary determinant of the success of the online learning process so they must continue to enrich their competencies and skills and be supported by school policies that encourage them to continue learning. Because, of course, the success of online learning cannot only be assessed from the aspect of skills using technology only. Also, the generation of digital natives will one day become teachers. So like it or not, the Indonesian curriculum must follow this "trend" and make developments in the use of technology in the future.

\section{References}

[1] et al Joseph Crawford, Butler-Henderson, Jurgen Rudolph, "COVID-19: 20 Countries' Higher Education Intra-Period Digital Pedagogy Responses,” J. Appl. Teach. Learn., vol. 3, no. 1, pp. 4-13, 2020. https://doi.org/10.37074/jalt.2020.3.1.7

[2] G. Kaur, "Digital Life: Boon or bane in teaching sector on COVID-19," CLIO an Annu. Interdiscip. J. Hist., vol. 6, no. 6, pp. 416-427, 2020.

[3] N. E. Collie, R. J., Shapka, J. D., \& Perry, "Predicting teacher commitment: The impact of school climate and social—Emotional learning," Psychol. Sch., no. 3, pp. 1034-1048, 2011, doi: 10.1037/a0029356.PREDICTING. https://doi.org/10.1002/pits.20611

[4] S. Suryadi, "Peranan Perkembangan Teknologi Informasi Dan Komunikasi Dalam Kegiatan Pembelajaran Dan Perkembangan Dunia Pendidikan,” J. Inform., vol. 3, no. 3, pp. 9-19, 2019. https://doi.org/10.36987/informatika.v3i3.219.

[5] S. Dhawan, "Online Learning: A Panacea in the Time of COVID-19 Crisis," J. Educ. Technol. Syst., vol. 49, no. 1, pp. 5-22, 2020, doi: 10.1177/0047239520934018.

[6] M. Mastur, M. Afifulloh, and L. N. A. B. Dina, "Upaya Guru Dalam Melaksanakan Pembelajaran Daring Pada Masa Pandemi Covid-19," JPMI J. Pendidik. Madrasah Ibtidaiyah, vol. 2, no. 3, pp. 72-81, 2002.

[7] Kompas Team, "The New Era of Education," 2020.

[8] W. Zhaohui, "How a top Chinese university is responding to coronavirus," World Economic Forum, 2020. https://www.weforum.org/agenda/2020/03/coronavirus-china-the-challengesof-online-learning-for-universities/

[9] B. Sumintono, S. Wibowo, N. Mislan, and D. Tiawa, "Jurnal Pengajaran MIPA, Volume 17, Nomor 1, April 2012 1," J. Pengajaran MIPA, vol. 17, no. 1, pp. 122-131, 2012. https://doi.org/10.18269/jpmipa.v17i1.251

[10] K. Nazgul, B. Anar, Z. Baglan, S. Moldir, G. Sadvakasova, and S. Nishanbayeva, "Preservice Teachers ' Opinions on the Use of Technology in Education," Int. J. Emerg. Technol. Learn., vol. 15, no. 23, pp. 182-192, 2020. https://doi.org/10.3991/ijet.v15i23.18831\%0d. https://doi.org/10.3991/ijet.v15i23.18831 
[11] S. Kessler, "8 Ways Technology Is Improving Education," 2010. https://mashable.com/ 2010/11/22/technology-in-education/

[12] M. Prensky, "Digital natives, digital immigrants," Horiz., vol. 9, no. 5, 2001.

[13] X. R. Guo, T. Dobson, and S. Petrina, "Digital natives, digital immigrants: An analysis of age and ICT competency in teacher education,” J. Educ. Comput. Res., vol. 38, no. 3, pp. 235-254, 2008. https://doi.org/10.2190/ec.38.3.a

[14] Suryanti and L. Wijayanti, "Literasi Digital : Kompetensi Mendesak Di Era Revolusi Industri 4.0,” J. Pendidik. Dasar, vol. II, no. 1, pp. 1-9, 2018.

[15] O. Zur and A. Walker, "On Digital Immigrants and Digital Natives : How the Digital Divide Affects Families, Educational Institutions , and the Workplace," Zurinstitute, no. October, pp. 1-13, 2011, [Online]. Available: http://www.zurinstitute.com/digital divide.html

[16] P. Thompson, "The digital natives as learners : Technology use patterns and approaches to learning."

[17] R. G. Ashari, "Memahami Hambatan dan Cara Lansia Mempelajari Media Sosial," J. ILMU Komun., vol. 15, no. 2, p. 155, 2018,. https://doi.org/10.24002/jik.v15i2.1245

[18] S. Vodanovich, D. Sundaram, and M. Myers, "Research Commentary-Digital Natives and Ubiquitous Information Systems," Inf. Syst. Res., 2010. https://doi.org/10.1287/isre. 1100.0324

[19] A. Kesharwani, "Do (how) digital natives adopt a new technology differently than digital immigrants? A longitudinal study," Inf. Manag., vol. 57, no. 2, 2020. https://doi.org/ 10.1016/j.im.2019.103170

[20] P. Tearle, "A theoretical and instrumental framework for implementing change in ICT in education."

[21] A. Marwan and T. Sweeney, "Teachers' perceptions of educational technology integration in an Indonesian polytechnic."

[22] P. Wahyono, H. Husamah, and A. S. Budi, "Guru profesional di masa pandemi COVID-19: Review implementasi, tantangan, dan solusi pembelajaran daring." https://doi.org/10. 31219/osf.io/btj7m

[23] A. K. Arora and R. Srinivasan, "Impact of Pandemic COVID-19 on the Teaching - Learning Process : A Study of Higher Education Teachers."

[24] W. L. Newman, Metode Penelitian Sosial: Pendekatan Kualitatif dan Kuantitatif (7th ed.).

[25] S. Siregar, Statistika Deskriptif untuk Penelitian: Dilengkapi Perhitungan Manual dan Aplikasi SPSS Versi 17. .

[26] L. A. Ritter and V. M. Sue, "Introduction to using online surveys," https://doi.org/10.1002/ ev.230

[27] N. Howe and W. Strauss, Millennials rising: The next great generation.

[28] C. L. Jurkiewicz, "Generation X and the Public Employee," 2000.

[29] S. Lyons, “An exploration of generational values in life and at work." 2003.

[30] C. Brown and L. Czerniewicz, "Debunking the 'digital native': Beyond digital apartheid, towards digital democracy,” J. Comput. Assist. Learn., vol. 26, no. 5, pp. 357-369, 2010, https://doi.org/10.1111/j.1365-2729.2010.00369.x

[31] A. J. Autry and Z. Berge, "Digital natives and digital immigrants: Getting to know each other," Ind. Commer. Train., vol. 43, no. 7, pp. 460-466, 2011. https://doi.org/10.1108/ $\underline{00197851111171890}$

[32] M. Prensky, "Overcoming educators' digital immigrant accents: a rebuttal," The Technology Source Archives, 2003. http://technologysource.org/article/overcoming_\%0Aeducators digital immigrant accents $\% 0 \mathrm{~A}$ 
[33] K. Purcell, A. Heaps, J. Buchannan, and L. Friedrich, "How Teachers Are Using Technology at Home and in Their Classrooms | Pew Research Center's Internet \& American Life Project," Pew Res. Cent., p. 108, 2013, [Online]. Available: http://www.pewinternet.org/ 2013/02/28/how-teachers-are-using-technology-at-home-and-in-their-classrooms/

[34] Sujoko, "Pemanfaatan Teknologi Informasi dan Komunikasi sebagai Media Pembelajaran di SMP Negeri 1 Geger Madiun,” Kebijak. dan Pengemb. Pendidik., vol. 1, no. 1, 2013. https://doi.org/10.32550/teknodik.v0i0.369

[35] K. Carey, "Everybody Ready for the Big Migration to Online College? Actually, No," The New York Times, Mar. 13, 2020.

[36] K.-J. Kim and C. J. Bonk, "The Future of Online Teaching and Learning in Higher Education: The Survey Says,” 2006. [Online]. Available: https://er.educause.edu/articles/2006/1/ the-future-of-online-teaching-and-learning-in-higher-education-the-survey-says

[37] J. Snelling and D. Fingal, "10 strategies for online learning during a coronavirus outbreak." https://www.iste.org/explore/learning-during-covid-19/10-strategies-online-learning-during-coronavirus-outbreak? hsenc=p2ANqtz- OQm31-LSZDyoj570XoVJWoNSUtj5IF1At05vuT9mL0 PaKQQYVhF7CDAlMOXNef0e8sNQ0FG3mRqPAqiLbTUhNJ YVXQ\& hsmi $=85961465$

[38] K. Mingsiritham, G. Chanyawudhiwan, C. Paiwithayasiritham, and N. Pathom, "Factor Analysis of Smart Social Media Technology to Promote Professional Learning Communities for Teachers,” Int. J. Interact. Mob. Technol., vol. 14, no. 20, pp. 165-173, 2020, doi: https://doi.org/10.3991/ijim.v14i20.17253

[39] A. Yunita, Nursechafia, E. Setiawan, H. Nugroho, and H. Ramadhan, "The relationship between mobile phone usage in classroom and academic achievement in college life," Int. J. Interact. Mob. Technol., vol. 12, no. 8, pp. 96-103, 2018. https://doi.org/10.3991/ ijim.v12i8.9530

[40] Kemendikbud, "Pedoman Pelaksanaan Belajar Dari Covid-19 Rumah Selama Darurat Bencana Di Indonesia Surat," no. 15, 2020.

[41] APJII, "Survei APJII: Penetrasi Internet di Indonesia Capai 143 Juta Jiwa," Buletin Asosiasi Penyelenggara Jasa Internet Indonesia, vol. Edisi-22 2. p. 3, 2018.

\section{$7 \quad$ Authors}

Prawinda Putri Anzari, Imamul Huda Al Shiddiq, Seli Septiana Pratiwi,

Megasari Noer Fatanti are from Universitas Negeri Malang, Malang, Indonesia.

Daniel Fritz V. Silvallana is from Davao del Norte State College, Phillipines.

danielfritz.silvallana@dnsc.edu.ph

Article submitted 2021-01-15. Resubmitted 2021-02-24. Final acceptance 2021-02-25. Final version published as submitted by the authors. 